University of New Hampshire

University of New Hampshire Scholars' Repository

\title{
$9-2015$
}

\section{Soil nitrogen affects phosphorus recycling: foliar resorption and plant-soil feedbacks in a northern hardwood forest}

\author{
Craig R. See \\ SUNY College of Environmental Science and Forestry \\ Ruth D. Yanai \\ SUNY College of Environmental Science and Forestry \\ Melany C. Fisk \\ Miami University \\ Matthew A. Vadeboncoeur \\ University of New Hampshire, matt.vad@unh.edu \\ Braulio A. Quintero \\ SUNY College of Environmental Science and Forestry
}

See next page for additional authors

Follow this and additional works at: https://scholars.unh.edu/ersc

\section{Recommended Citation}

Craig R. See, Ruth D. Yanai, Melany C. Fisk, Matthew A. Vadeboncoeur, Braulio A. Quintero, and Timothy J. Fahey 2015. Soil nitrogen affects phosphorus recycling: foliar resorption and plant-soil feedbacks in a northern hardwood forest. Ecology 96:2488-2498. http://dx.doi.org/10.1890/15-0188.1

This Article is brought to you for free and open access by the Institute for the Study of Earth, Oceans, and Space (EOS) at University of New Hampshire Scholars' Repository. It has been accepted for inclusion in Earth Systems Research Center by an authorized administrator of University of New Hampshire Scholars' Repository. For more information, please contact Scholarly.Communication@unh.edu. 


\section{Authors}

Craig R. See, Ruth D. Yanai, Melany C. Fisk, Matthew A. Vadeboncoeur, Braulio A. Quintero, and Timothy J. Fahey 


\title{
Soil nitrogen affects phosphorus recycling: foliar resorption and plant-soil feedbacks in a northern hardwood forest
}

\author{
Craig R. See, ${ }^{1}$ Ruth D. Yanai, ${ }^{1,5}$ Melany C. Fisk, ${ }^{2}$ Matthew A. Vadeboncoeur, ${ }^{3}$ Braulio A. Quintero, ${ }^{1}$ \\ and Timothy J. FAHEY ${ }^{4}$ \\ ${ }^{1}$ Department of Forest and Natural Resources Management, SUNY College of Environmental Science and Forestry, \\ Syracuse, New York 13210 USA \\ ${ }^{2}$ Department of Zoology, Miami University, Oxford, Ohio 45056 USA \\ ${ }^{3}$ Earth Systems Research Center, University of New Hampshire, Durham, New Hampshire 03824 USA \\ ${ }^{4}$ Department of Natural Resources, Cornell University, Ithaca, New York 14853 USA
}

\begin{abstract}
Previous studies have attempted to link foliar resorption of nitrogen and phosphorus to their respective availabilities in soil, with mixed results. Based on resource optimization theory, we hypothesized that the foliar resorption of one element could be driven by the availability of another element. We tested various measures of soil $\mathrm{N}$ and $\mathrm{P}$ as predictors of $\mathrm{N}$ and $\mathrm{P}$ resorption in six tree species in 18 plots across six stands at the Bartlett Experimental Forest, New Hampshire, USA. Phosphorus resorption efficiency $(P<0.01)$ and proficiency $(P=0.01)$ increased with soil $\mathrm{N}$ content to $30 \mathrm{~cm}$ depth, suggesting that trees conserve $\mathrm{P}$ based on the availability of soil $\mathrm{N}$. Phosphorus resorption also increased with soil $\mathrm{P}$ content, which is difficult to explain based on single-element limitation, but follows from the correlation between soil $\mathrm{N}$ and soil $\mathrm{P}$. The expected single-element relationships were evident only in the $\mathrm{O}$ horizon: $\mathrm{P}$ resorption was high where resin-available $\mathrm{P}$ was low in the Oe $(P<$ 0.01 for efficiency, $P<0.001$ for proficiency) and $\mathrm{N}$ resorption was high where potential $\mathrm{N}$ mineralization in the Oa was low $(P<0.01$ for efficiency and 0.11 for proficiency). Since leaf litter is a principal source of $\mathrm{N}$ and $\mathrm{P}$ to the $\mathrm{O}$ horizon, low nutrient availability there could be a result rather than a cause of high resorption. The striking effect of soil $\mathrm{N}$ content on foliar $\mathrm{P}$ resorption is the first evidence of multiple-element control on nutrient resorption to be reported from an unmanipulated ecosystem.
\end{abstract}

Key words: Acer rubrum; Acer saccharum; Betula alleganiensis; Betula papyrifera; Fagus grandifolia; MELHNE; Prunus pensylvanica; stoichiometry.

\section{INTRODUCTION}

Over the last century, humans have more than doubled the amount of reactive $\mathrm{N}$ in the biosphere (Galloway et al. 2003). By relieving chronic $\mathrm{N}$ limitation, increased $\mathrm{N}$ availability is expected to increase biological demand for $\mathrm{P}$ in terrestrial ecosystems (Vitousek et al. 2010, Cleveland et al. 2013). In response to changes in nutrient availability, organisms should maximize the acquisition and internal conservation of their most limiting resources (Bloom et al. 1985), maintaining insofar as possible a stoichiometric balance (Rastetter et al. 2013). This balance is achieved by optimizing the allocation of effort towards both acquisition and conservation of limiting nutrients.

Nutrient resorption, the withdrawal of nutrients from leaves to other plant tissues prior to abscission, is one of the most important nutrient conservation mechanisms used by perennial plants (Killingbeck 1986). Resorption is commonly reported in two ways. Resorption efficiency

Manuscript received 29 January 2015; accepted 6 March 2015; final version received 30 March 2015. Corresponding Editor: R. A. Dahlgren.

${ }^{5}$ Corresponding author. E-mail: rdyanai@syr.edu is the percent difference between litterfall nutrient concentration and the concentration found in green leaves. Resorption proficiency is the concentration to which nutrients have been reduced in litterfall (Killingbeck 1996). Globally, resorption is estimated to supply $31 \%$ of annual plant demand for $\mathrm{N}$ and $40 \%$ for $\mathrm{P}$ (Cleveland et al. 2013). By controlling litterfall nutrient concentrations, resorption also influences litterfall nutrient flux and hence the return of organic $\mathrm{N}$ and $\mathrm{P}$ to soil (Vergutz et al. 2012).

Because resorption is a mechanism of conserving nutrients, one might expect resorption of an element to increase as the availability of that element decreases. A recent meta-analysis of fertilization experiments has shown this to be the case globally (Yuan and Chen 2015), but the relationship between foliar resorption and soil nutrients is not consistent at local scales (Aerts 1996, Aerts and Chapin 2000, Yuan and Chen 2015). While studies in some systems have shown the expected inverse correlation between resorption and soil availability (Stachurski and Zimka 1975, Boerner 1984, Aerts and De Caluwe 1994), many have found no relationship (Schlesinger et al. 1989, Chapin and Moilanen 1991, Bowman et al. 1995), and some have even found 
TABLE 1. Description of stands in Bartlett Experimental Forest, New Hampshire, USA.

\begin{tabular}{lcclcl}
\hline \hline Site & Clearcut & Elevation $(\mathrm{m})$ & Aspect & Slope & \multicolumn{1}{c}{ Species composition } \\
\hline C1 & 1990 & 570 & SE & $5-20 \%$ & PRPE, BEPA, FAGR, ACRU \\
C2 & 1988 & 340 & NE & $15-30 \%$ & FAGR, ACRU, PRPE, BEPA, BEAL \\
C4 & 1978 & 410 & NW & $20-25 \%$ & BEPA, POGR, FAGR, PRPE, BEAL, ACRU \\
C6 & 1975 & 460 & NNW & $13-20 \%$ & BEAL, FAGR, ACRU, BEPA, PRPE, ACSA \\
C8 & 1883 & 330 & NE & $5-35 \%$ & FAGR, ACSA, BEAL, ACRU \\
C9 & $\sim 1890$ & 440 & NE & $10-35 \%$ & ACSA, FAGR, BEAL \\
\hline
\end{tabular}

Notes: Species composition is listed in order of decreasing basal area. Species codes are PRPE (Prunus pensylvanica), ACRU (Acer rubrum), BEPA (Betula papyrifera), FAGR (Fagus grandifolia), BEAL (B. alleghaniensis), ACSA (A. saccharum), and POGR (Populus grandidentata). Aspect abbreviations are SE, southeast; NE, northeast; NW, northwest; and NNW, north-northwest.

resorption to increase with increasing soil nutrient availability (Boerner 1986, Nambiar and Fife 1987, Sabate et al. 1995).

Leaf nutrient status has been used as another indicator of nutrient availability in attempts to explain patterns of nutrient resorption, also with mixed results. Globally, leaves with high concentrations of a nutrient have lower resorption efficiencies for that nutrient (Kobe et al. 2005, Vergutz et al. 2012), but this trend is not always seen at local scales (Enoki and Kawaguchi 1999, Norby et al. 2000, Lal et al. 2001). This inconsistency among studies at different sites led Aerts and Chapin (2000) to conclude that while resorption is important to plant nutrient conservation and ecosystem nutrient cycling, there are no clear nutritional controls over resorption.

This lack of consistency among resorption studies may arise in part because most studies of the relationship between resorption and nutrient limitation have used a single element model, separately comparing $\mathrm{N}$ availability to $\mathrm{N}$ resorption, and $\mathrm{P}$ availability to $\mathrm{P}$ resorption. It is now clear that the productivity of many terrestrial ecosystems traditionally thought of as $\mathrm{N}$ limited are instead co-limited by $\mathrm{N}$ and $\mathrm{P}$ (Elser et al. 2007, Harpole et al. 2011), which has spurred interest in relating the stoichiometry of $\mathrm{N}$ and $\mathrm{P}$ resorption to nutrient limitation. Some recent studies have found that $\mathrm{N}$ and $\mathrm{P}$ resorption vary relative to each other across gradients of $\mathrm{N}$ and $\mathrm{P}$ limitation. This has been shown by comparing N:P ratios between green and senesced leaves (Richardson et al. 2008), the ratio of $\mathrm{N}$ and $\mathrm{P}$ resorption efficiencies (Reed et al. 2012), and the difference between $\mathrm{N}$ and $\mathrm{P}$ resorption efficiencies (Han et al. 2013). Collectively, these studies point to resorption as a way for plants to balance their demand for these elements in response to variations in environmental availability. Hence, multiple-element controls deserve attention for understanding patterns of resorption and its significance in ecosystem nutrient dynamics.

Multiple-element controls may be particularly relevant in northern hardwood forests, where a regional meta-analysis of fertilization experiments has shown productivity to be primarily $\mathrm{N}$-limited but with $\mathrm{P}$ often co-limiting (Vadeboncoeur 2010). Optimization theory predicts that the effort allocated towards the resorption of a nutrient should be proportional to its demand relative to other nutrients (Bloom et al. 1985, Rastetter et al. 2013). Thus where $\mathrm{P}$ limitation is secondary to that of N (Vadeboncoeur 2010), P resorption may depend more on the availability of $\mathrm{N}$ than on the availability of $\mathrm{P}$. These interactions are predicted based on theory, but should be tested by observing the relationship between $\mathrm{P}$ resorption and ecosystem $\mathrm{N}$ status.

We compared $\mathrm{N}$ and $\mathrm{P}$ resorption efficiencies and proficiencies to measures of soil and foliar chemistry in 18 plots in six northern hardwood stands in New Hampshire. We tested for both single-element and multiple-element explanations for patterns in resorption; we predicted that resorption of $\mathrm{P}$ would depend on availability of $\mathrm{N}$. Nutrient availability was measured both in the $\mathrm{O}$ horizon (resin-available $\mathrm{P}$ and $\mathrm{N}$ mineralization potential) and also in soils to $30 \mathrm{~cm}$ depth, where it was less likely that foliar resorption was the cause of differences in $\mathrm{N}$ and $\mathrm{P}$ availability. We evaluated $\mathrm{N}$ and $\mathrm{P}$ resorption for the six most common species in these stands and for the community-level weighted average based on species contributions to leaf litterfall in each of the 18 plots.

\section{Methods \\ Site description}

This study took place in the Bartlett Experimental Forest in the White Mountains of New Hampshire, USA. Soils are well-drained Spodosols formed in granitic glacial drift deposited $\sim 14000 \mathrm{yr}$ BP. These stands have a history of logging, and stands are largely even-aged. We present data from 18 previously established plots, three in each of six stands (Table 1), ranging in age from 21-126 years at the time leaves were sampled and varying in soil $\mathrm{N}$ and $\mathrm{P}$ pools (Vadeboncoeur et al. 2014).

Within each stand, three $30 \times 30 \mathrm{~m}$ plots were established. Dominant tree species in the younger stands included Fagus grandifolia (Ehrh.), Betula papyrifera (Marsh.), Acer rubrum L., and Prunus pensylvanica (L. f.). Older stands were dominated by $F$. grandifolia, $A$. saccharum (Marsh.), and B. alleghaniensis (Britton). Mid-aged stands included a mixture of all species, along with Populus grandidentata (Michx.). 


\section{Soil nitrogen and phosphorus}

In each plot, one $0.5-\mathrm{m}^{2}$ quantitative soil pit was excavated in 2004, as described by Vadeboncoeur et al. (2012). For this study, we used data from the Oa horizon and the $0-10$ and $10-30 \mathrm{~cm}$ depth increments in the mineral soil; $86 \%$ of the roots occur above $30 \mathrm{~cm}$ depth in these sites (Park et al. 2007).

Four soil $\mathrm{P}$ fractions were determined for each depth increment using a sequential extraction procedure (Nezat et al. 2007, Vadeboncoeur et al. 2014). The first extraction used a neutral salt, $1 \mathrm{M} \mathrm{NH} \mathrm{NH}_{4} \mathrm{Cl}$, conventionally used for exchangeable cations. The residue was extracted in $30 \% \mathrm{H}_{2} \mathrm{O}_{2}$ to determine organically bound $\mathrm{P}$. That residue was extracted in $1 \mathrm{~mol} / \mathrm{L} \mathrm{HNO}_{3}$ at $10^{\circ} \mathrm{C}$ to dissolve apatite-bound $\mathrm{P}$ in contact with the solution. Apatite is the primary source of $\mathrm{P}$ from mineral weathering, and using our method a previous study showed estimates of soil apatite correlate with litterfall $\mathrm{P}$ in northern hardwood forests (Lucash et al. 2012). Finally, the residue from the apatite digestion was further digested in concentrated $\mathrm{HNO}_{3}$ at $150^{\circ} \mathrm{C}$ for $3 \mathrm{~h}$ to estimate the amount of apatite $\mathrm{P}$ armored in biotite and chlorite. These four $\mathrm{P}$ fractions probably account for $>70 \%$ of total soil $\mathrm{P}$ (Nezat et al. 2007). A more complete digestion would be required to dissolve the more refractory silicate minerals, which can also shield apatite inclusions. The $\mathrm{P}$ concentration of each extract was determined using inductively coupled plasma optical emission spectroscopy (ICP-OES, PE-3300DV; PerkinElmer, Norwalk, Connecticut, USA).

Total soil carbon and $\mathrm{N}$ concentrations were determined using a $\mathrm{CN}$ elemental analyzer (CE Instruments Model NC2100; CE Elantech, Lakewood, New Jersey, USA).

We calculated the $\mathrm{N}, \mathrm{P}$, and $\mathrm{C}$ content of the soil pit in each plot as the sum of the contents of the three depth increments, each the product of the dry soil mass and nutrient concentration. We also calculated weighted average concentrations by dividing nutrient contents by soil mass, but found pools to be slightly better predictors of resorption (Appendix A). We calculated the sum of $\mathrm{P}$ extracted at each of the steps in the sequence. We refer to the sum of the neutral salt and $\mathrm{H}_{2} \mathrm{O}_{2}$ extractions as "recyclable P." Although much of the organically bound $\mathrm{P}$ in the recyclable pool is not made available to plants during a single growing season, much of it is likely available on a decadal timescale (Richter et al. 2006). The later steps in the sequence dissolve $\mathrm{P}$ that will become available only after further weathering of primary minerals (Nezat et al. 2007), and primary mineral weathering rates are small relative to annual plant demand (Yanai 1992).

We also measured soil $\mathrm{N}$ and $\mathrm{P}$ availability in 2009 in the Oe and Oa horizons, as this is where recycled nutrients are most highly concentrated. We took $\sim 302$ $\mathrm{cm}$ diameter soil cores from each plot and combined them by horizon. We assessed the $\mathrm{N}$ mineralization potential over a 21-day laboratory incubation period, described by Fisk et al. (2013). We estimated potentially mineralizable $\mathrm{P}$ by extracting soil subsamples in $0.5 \mathrm{~mol} /$ L sodium bicarbonate at $\mathrm{pH} 8.5$ (Olsen et al. 1954), digesting the extracts by persulfate oxidation, and analyzing total dissolved $\mathrm{P}$ with the ammoniummolybdate-ascorbic acid method (Murphy and Riley 1962). We measured available inorganic phosphate by shaking soil subsamples in deionized water with anion exchange resin bags, then extracting resin-bound $\mathrm{P}$ in 0.5 $\mathrm{mol} / \mathrm{L} \mathrm{HCl}$.

\section{Foliar nutrient sampling}

Green leaves were collected during the first week of August in 2009 and 2010. Between one and five trees of each species were sampled in each plot, depending on the abundance of the species. Leaves were collected from sun-exposed areas of the mid-canopy of each tree using pole pruners or shotgun, depending on tree height. About 20-30 leaves were combined by tree for analysis of nutrient concentrations.

\section{Leaf litter collections}

Freshly fallen litter was collected from all plots in autumn 2009 and 2010 for nutrient analysis. Net traps were hung at three locations within each plot to catch litter falling between rain events. Litter from each species in each trap was analyzed for nutrient concentrations.

To obtain $\mathrm{P}$ concentrations, $0.25 \mathrm{~g}$ of sample was oven dried at $60^{\circ} \mathrm{C}$, ashed in a muffle furnace at $470^{\circ} \mathrm{C}$, digested in $6 \mathrm{~mol} / \mathrm{L} \mathrm{HNO}_{3}$, and analyzed with ICP-OES. Foliar $\mathrm{N}$ concentrations were determined using a $\mathrm{CN}$ elemental analyzer (EA1112 elemental analyzer; Thermo Electron Corporation, Waltham, Massachusetts, USA). Concentrations of $\mathrm{N}$ and $\mathrm{P}$ obtained from reference leaf material (NIST SRM 1515) analyzed with our samples were within $5 \%$ of certified values.

In all plots, five baskets each with a collection area of $0.23 \mathrm{~m}^{2}$ were used to estimate the mass of litterfall by species. Litter collected from August to November in 2009 was sorted to species, and litter masses for each basket were recorded after oven drying at $60^{\circ} \mathrm{C}$ to constant mass.

\section{Data analysis}

We used plots as our experimental units, because leaf litter could not be paired with green foliage by tree and because there was one soil measurement in each plot. Nutrient concentrations of leaf litter and green foliage for each species were averaged within plot for 2009 and 2010. Plot-level values were then averaged across years.

Resorption proficiency was reported as the nutrient concentration of leaf litter. Resorption efficiency was calculated on a dry mass basis as $\left(N_{\mathrm{gr}}-N_{\text {lit }}\right) / N_{\mathrm{gr}}$, where $N_{\mathrm{gr}}$ was the nutrient concentration found in green foliage, and $N_{\text {lit }}$ was the concentration of litterfall. This calculation ignores $\mathrm{C}$ resorption and $\mathrm{C}$ and nutrient losses due to leaching during senescence. The bias 
TABLE 2. Results of mixed linear models showing the effects of soil and fresh foliar variables on nutrient resorption across plots $(n$ $=18$ plots) while treating stand as a random effect.

\begin{tabular}{|c|c|c|c|c|c|c|}
\hline Variables & $\begin{array}{l}\mathrm{P} \text { resorption } \\
\text { efficiency }\end{array}$ & $\begin{array}{l}\text { Litterfall P } \\
(\mathrm{mg} / \mathrm{g})\end{array}$ & $\begin{array}{l}\mathrm{N} \text { resorption } \\
\text { efficiency }\end{array}$ & $\begin{array}{l}\text { Litterfall N } \\
\quad(\mathrm{mg} / \mathrm{g})\end{array}$ & $\begin{array}{l}\mathrm{N}: \mathrm{P} \text { resorption } \\
\text { ratio }\end{array}$ & $\begin{array}{l}\text { Litterfall } \\
\mathrm{N}: \mathrm{P} \text { ratio }\end{array}$ \\
\hline Soil C pool $\left(\mathrm{g} / \mathrm{m}^{2}\right)$ & $\uparrow 0.15$ (0.08) & $\downarrow 0.23(0.04)$ & $\uparrow 0.11(0.13)$ & $\downarrow 0.03(0.22)$ & $\downarrow 0.10(0.19)$ & $\uparrow 0(0.93)$ \\
\hline Soil $\mathrm{N}$ pool $\left(\mathrm{g} / \mathrm{m}^{2}\right)$ & $\uparrow \mathbf{0 . 3 7}(<\mathbf{0 . 0 1 )}$ & $\downarrow 0.34(0.01)$ & $\uparrow 0.10(0.16)$ & $\downarrow 0.02(0.36)$ & $\downarrow 0.16(0.10)$ & $\uparrow 0.02(0.37)$ \\
\hline Soil recyclable P pool $\left(\mathrm{g} / \mathrm{m}^{2}\right)$ & $\uparrow 0.08(0.20)$ & $\downarrow 0.15(0.09)$ & $\uparrow 0.01(0.74)$ & $\downarrow 0.03(0.29)$ & $\downarrow 0.09(0.15)$ & $\downarrow 0(0.68)$ \\
\hline $\begin{array}{l}\text { Soil recyclable } \mathrm{P}+\text { apatite } \mathrm{P} \\
\text { pool }\left(\mathrm{g} / \mathrm{m}^{2}\right)\end{array}$ & $\uparrow 0(0.85)$ & $\uparrow 0(0.85)$ & $\downarrow 0(0.85)$ & $\uparrow 0.01(0.61)$ & $\uparrow 0.02(0.58)$ & $\uparrow 0.17(0.07)$ \\
\hline $\begin{array}{l}\text { Sum of all soil P leaches pool } \\
\left(\mathrm{g} / \mathrm{m}^{2}\right)\end{array}$ & $\downarrow 0.02(0.57)$ & $\uparrow 0.07(0.27)$ & $\downarrow 0.01(0.77)$ & $\uparrow 0.01(0.60)$ & $\uparrow 0.09(0.18)$ & $\uparrow 0.05(0.28)$ \\
\hline $\begin{array}{l}\text { Soil N:P ratio (sum of all } \mathrm{P} \\
\text { leaches) }\end{array}$ & $\uparrow 0.04(0.39)$ & $\downarrow 0.07(0.26)$ & $\uparrow 0.07(0.29)$ & $\downarrow 0.02(0.44)$ & $\downarrow 0.04(0.40)$ & $\uparrow 0(0.82)$ \\
\hline 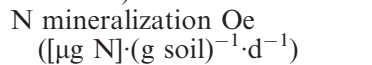 & $\downarrow 0.01(0.61)$ & $\downarrow 0(0.84)$ & $\downarrow 0.08(0.28)$ & $\uparrow 0.07(0.20)$ & $\downarrow 0.02(0.57)$ & $\downarrow 0.02(0.34)$ \\
\hline $\begin{array}{l}\mathrm{N} \text { mineralization Oa } \\
\left([\mu \mathrm{g} \mathrm{N}] \cdot(\mathrm{g} \text { soil })^{-1} \cdot \mathrm{d}^{-1}\right)\end{array}$ & $\downarrow 0.02(0.44)$ & $\downarrow 0(0.97)$ & $\downarrow 0.42(<0.01)$ & $\uparrow 0.07(0.11)$ & $\downarrow 0.01(0.65)$ & $\uparrow 0(0.69)$ \\
\hline Resin-available P Oe $(\mu \mathrm{g} / \mathrm{g})$ & $\downarrow 0.33(<0.01)$ & $\uparrow 0.54(<0$ & $\uparrow 0.01$ & $\downarrow 0.0$ & $\uparrow \mathbf{0 . 6}$ & $\downarrow 0.05$ \\
\hline Resin-available P Oe $(\mu \mathrm{g} / \mathrm{g})$ & $\downarrow 0(0.87)$ & $\uparrow 0.02(0.57)$ & $\uparrow 0.09(0.19)$ & $\downarrow \mathbf{0 . 1 1}(\mathbf{0 . 0 3})$ & $\uparrow 0.06(0.22)$ & $\downarrow 0.02(0.28)$ \\
\hline Green leaf $N(\mathrm{mg} / \mathrm{g})$ & $\uparrow 0(0.97)$ & $\downarrow 0.01(0.80)$ & $\downarrow 0.06(0.37)$ & $\uparrow 0.12(0.19)$ & $\downarrow 0.02(0.66)$ & $\downarrow 0.01(0.57)$ \\
\hline Green leaf P (mg/g) & $\downarrow 0.36(<0.01)$ & $\uparrow 0.64(<0.001)$ & $\downarrow 0(0.81)$ & $\uparrow 0.01(0.59)$ & $\uparrow 0.51(0.001)$ & $\downarrow 0.20(0.02)$ \\
\hline Green leaf N:P & $\uparrow 0.13(0.17)$ & $\downarrow 0.33(0.02)$ & $\downarrow 0.02(0.63)$ & $\uparrow 0(0.89)$ & $0.37(0.02)$ & $\uparrow 0.05(0.28)$ \\
\hline
\end{tabular}

Notes: Marginal $R^{2}$ values indicate the strength of the correlation between the two variables, while the arrows indicate the direction (arrows pointing up indicate a positive correlation, arrows pointing down indicate a negative correlation). $P$ values for the coefficient are shown in parentheses; cells with significant $P$ values are shown in boldface type. Soil pit contents used in the analysis were estimates of total pit content $\left(\mathrm{g} / \mathrm{m}^{2}\right)$ from the Oa horizon to $30 \mathrm{~cm}$ depth in the mineral soil. Foliar chemistry and resorption efficiencies reflect the plot mean of all species weighted by contribution to plot litterfall mass.

introduced by these omissions is likely to be systematic and have little influence on the relationship between the calculated efficiencies and our explanatory variables.

Community-level foliar concentrations and resorption efficiencies were calculated for each plot from the mean concentrations and resorption efficiencies of the component tree species, weighting each species by its contribution to the total litterfall mass of the plot. We excluded the minor species for which we did not have concentration data, so that the sum of the study species totaled $100 \%$. Minor species accounted for an average of $4 \%$ of litter mass (range 0.1-15\%). Community-level estimates of foliar N:P ratios were calculated as the mass ratio of community-level $\mathrm{N}$ and $\mathrm{P}$ concentrations.

We used a one-way ANOVA to test for differences in resorption efficiencies and proficiencies among species. Comparisons of species means were conducted using Tukey's honestly significant difference test.

We used mixed linear models treating stand as a random effect to describe resorption as a function of soil and leaf chemistry across plots $(n=18)$ using the nlme package in R (Pinheiro et al. 2014). Dependent variables were resorption efficiency and proficiency of $\mathrm{N}$ and $\mathrm{P}$. Predictor variables (each considered separately) were green foliar concentrations, $\mathrm{N}$ mineralization rates, resin and bicarbonate-extractable $\mathrm{P}$ concentrations, total soil $\mathrm{N}$ and $\mathrm{C}$ content, and content of the various soil $\mathrm{P}$ fractions measured in soil pits. We calculated the marginal $R^{2}$ as outlined by Nakagawa and Schielzeth (2013) to describe the proportion of variance explained by each fixed effect using the MuMIn package (Barton 2014). We used a similar approach to examine the relationship between our various soil predictor vari- ables, by considering each pair separately with mixedlinear models controlling for stand effects.

We scaled all comparisons up to the stand level $(n=$ 6 ), by using the mean of the three plot-level values for each stand. We compared $\mathrm{N}$ and $\mathrm{P}$ resorption efficiency and proficiency to the same predictor variables that we used in the plot-level analyses. Stand-level analyses were conducted using simple linear regression. To examine the relationship between the soil predictor variables in this case we used simple linear regression (correlation).

\section{RESUlTS \\ Community-level $N$ and $P$ resorption}

Community-level P resorption efficiency (37-80\%, CV $=16 \%$ ) was more variable than $\mathrm{N}$ resorption efficiency $(47-65 \%, \mathrm{CV}=8 \%)$ across our plots. In litter, $\mathrm{P}$ concentrations were much more variable $(\mathrm{CV}=40 \%)$ than $\mathrm{N}$ concentrations $(\mathrm{CV}=16 \%)$. Conversely, green foliar concentrations of both $\mathrm{N}(\mathrm{CV}=10 \%)$ and $\mathrm{P}(\mathrm{CV}=$ $12 \%$ ) were more consistent. Litterfall $\mathrm{N}: \mathrm{P}$ ratios were considerably more variable $(8-45)$ than the $\mathrm{N}: \mathrm{P}$ ratio in foliage (13-22), reflecting the high variability in $\mathrm{P}$ resorption .

Foliar concentrations have been used as an indicator of nutrient availability in explaining nutrient resorption. Variation across plots in $\mathrm{P}$ resorption was related to foliar P concentrations, based on mixed linear models including stand as a random effect (Table 2). As expected, $\mathrm{P}$ resorption efficiency and proficiency both declined with increasing foliar $\mathrm{P}$ across our plots, as litter was high in $\mathrm{P}$ where foliage was high in $\mathrm{P}$. As a result, where foliar $\mathrm{P}$ was high, litterfall $\mathrm{N}: \mathrm{P}$ ratios were low. In contrast, foliar $\mathrm{N}$ concentrations, which varied 


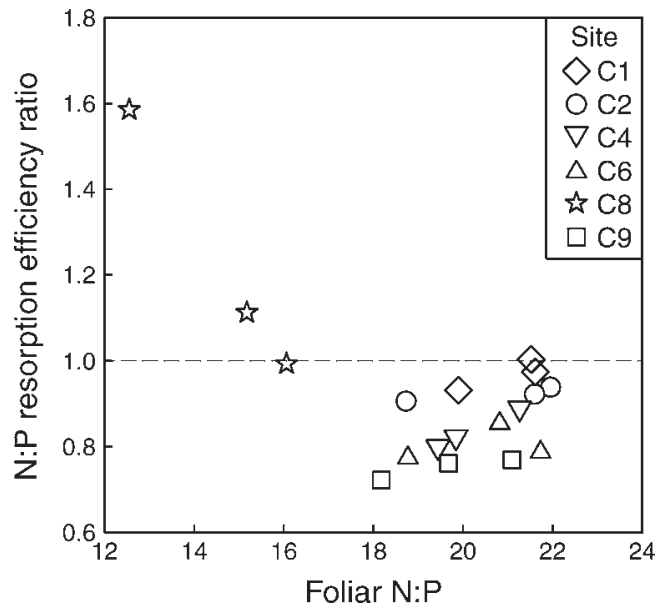

FIG. 1. Community-level N:P resorption ratio as a function of foliar N:P ratio (mass basis). Trees in plots where the foliar $\mathrm{N}: \mathrm{P}$ indicated a higher degree of $\mathrm{N}$ limitation resorbed proportionately more $\mathrm{N}$ than $\mathrm{P}$.

less across our plots, did not explain variation in $\mathrm{N}$ resorption or litterfall N:P.

The stoichiometry of resorption reflected the stoichiometry of foliage. In plots with the lowest foliar N:P concentrations, proportionately more $\mathrm{N}$ than $\mathrm{P}$ was resorbed during senescence (Fig. 1, Table 2). Although statistically significant, this relationship was driven by plots in a single stand (C8). Concentrations of $\mathrm{P}$ in both green foliage and litter in C8-3 were the highest among all of our plots, and $\mathrm{P}$ resorption efficiency the lowest. However, $\mathrm{N}$ concentrations of leaves and litter were not the lowest in this plot, and $\mathrm{N}$ resorption not the highest. Plot C8-3 also had the smallest soil $\mathrm{N}$ pool, the lowest $\mathrm{N}$ mineralization rates, and the highest concentrations of resin and bicarbonate-extractable $\mathrm{P}$ in the Oe horizons.
Unlike resorption, where $\mathrm{P}$ was more variable than $\mathrm{N}$ across plots, our estimates of soil availability showed greater variability in $\mathrm{N}$ than $\mathrm{P}$. In the Oe horizon, $\mathrm{N}$ mineralization potentials ranged from $7-67 \mu \mathrm{g} \cdot \mathrm{g}^{-1} \cdot \mathrm{d}^{-1}$ $(\mathrm{CV}=68 \%)$, while resin available phosphate ranged from $8-34 \mu \mathrm{g} / \mathrm{g}(\mathrm{CV}=38 \%)$. In the Oa horizon, the variability in $\mathrm{N}$ mineralization $\left(3-16 \mu \mathrm{g} \cdot \mathrm{g}^{-1} \cdot \mathrm{d}^{-1} ; \mathrm{CV}=\right.$ $41 \%)$ and resin $\mathrm{P}(7-19 \mu \mathrm{g} / \mathrm{g} ; \mathrm{CV}=38 \%)$ were similar, as were pools of soil $\mathrm{N}(\mathrm{CV}=25 \%)$ and of recyclable $\mathrm{P}(\mathrm{CV}$ $=29 \%$ ) to $30-\mathrm{cm}$ depth.

Our comparisons of resorption with nutrient availability in the $\mathrm{O}$ horizon yielded some support for singleelement controls over resorption. Nitrogen resorption efficiency was low where soil $\mathrm{N}$ mineralization rates in the Oa horizon were high $(P<0.01$, Table 2$)$ based on the plot-level data. When plot-level data were averaged to yield stand-level values, this relationship was still highly significant $(P<0.01$, Fig. 2a). Like $\mathrm{N}$ resorption efficiency, $\mathrm{N}$ resorption proficiency also decreased with increasing $\mathrm{N}$ mineralization rates $(P=0.11$ across plots, Table 2; $P=0.01$ across stands, data not shown).

For $\mathrm{P}$, too, the expected single-element relationship was observed between resorption and nutrient availability in the $\mathrm{O}$ horizon. Plot-level $\mathrm{P}$ resorption efficiency and proficiency were lower where resin-available $\mathrm{P}$ in the Oe horizon was higher (Table 2). At the stand level, this inverse relationship between $\mathrm{P}$ resorption and resin $\mathrm{P}$ in the Oe was more significant for resorption proficiency $(P$ $=0.04)$ than for efficiency $(P=0.14$, Fig. 2b). Surprisingly, bicarbonate-extractable $\mathrm{P}$ was not related to $\mathrm{P}$ resorption efficiency or proficiency (Table 2).

There was some support for multiple-element interactions in the relationship between $\mathrm{N}$ resorption and $\mathrm{P}$ availability. Nitrogen resorption proficiency (but not efficiency) was high where resin $\mathrm{P}$ was high in the Oa horizon $(P=0.03$, Table 2$)$, but this could be due to the
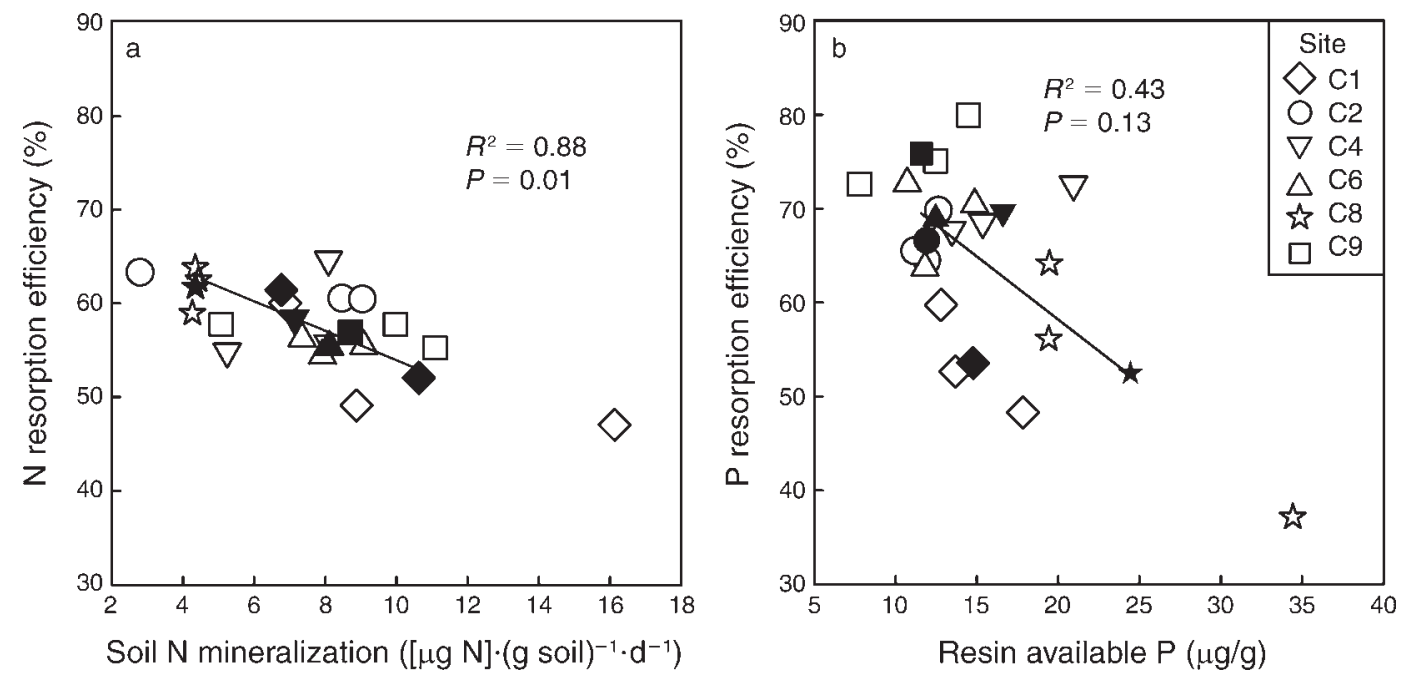

FIG. 2. (a) Community-level $\mathrm{N}$ resorption efficiency as a function of soil $\mathrm{N}$ mineralization rate in the Oa horizon and (b) $\mathrm{P}$ resorption efficiency as a function of resin-available $\mathrm{P}$ in the Oe horizon. Solid shapes depict stand means. Individual plots are shown as open shapes. Lines and fit statistics reflect simple linear regression of stand means ( $n=6$ replicates). 

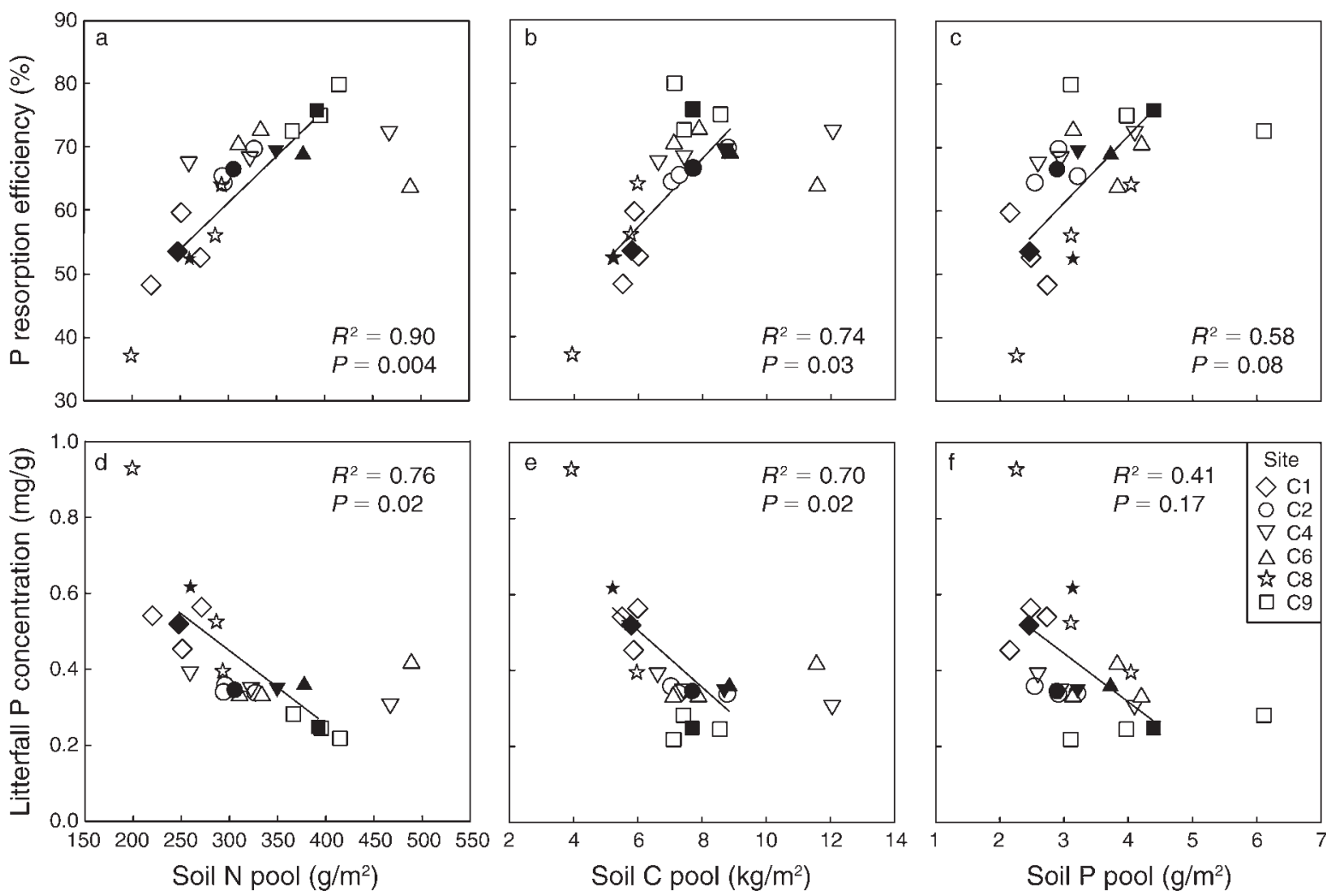

FIG. 3. Community-level resorption estimates as a function of soil nutrient pools. Lines and fit statistics are for simple linear regressions based on stand means ( $n=6$ replicates). Soil $\mathrm{N}$ content from the $\mathrm{Oa}$ to $30 \mathrm{~cm}$ depth is strongly correlated with both $\mathrm{P}$ resorption efficiency and proficiency (panels a and d). Phosphorus resorption was also correlated with soil C (panels b and e), but the relationship was weaker than with soil N. Soil content of recyclable $\mathrm{P}$ (the sum of peroxide and neutral salt extractions) was marginally correlated with P resorption efficiency (panel c), but not with litter P concentration (panel f). Solid shapes depict stand means and open shapes depict individual plots.

correlation between resin $\mathrm{P}$ and $\mathrm{N}$ mineralization potential. For $\mathrm{P}$, neither resorption efficiency nor proficiency related to measures of $\mathrm{N}$ mineralization in the O horizon (Table 2).

We considered $\mathrm{N}$ and $\mathrm{P}$ pools in the soil profile to 30 $\mathrm{cm}$ depth, where there was less chance than in the $\mathrm{O}$ horizon that variation in soil nutrient availability across our plots reflected variation in litterfall chemistry. Here we did not see the expected single-nutrient relationship between community-level nutrient resorption and soil nutrient pool size. However, we did find evidence of multiple element interactions. Community-level $\mathrm{P}$ resorption efficiency $(P<0.01)$ and proficiency $(P=0.01)$ were both high in plots where soil $\mathrm{N}$ pools were high (Table 2). The positive relationship between $\mathrm{P}$ resorption and soil $\mathrm{N}$ content was even stronger when considered at the stand level (Fig. 3a,d). Phosphorus resorption efficiency and proficiency were also related to soil C content (Table 2, Fig. 3b, e), presumably because soil $\mathrm{C}$ pool size was correlated with soil $\mathrm{N}$ pools (Appendix B). There were also marginally significant positive correlations between soil recyclable $\mathrm{P}$ pools and $\mathrm{P}$ resorption efficiency at the stand level $(P=0.08$, Fig. $3 \mathrm{c})$ and proficiency at the plot level $(P=0.09$, Table 2$)$.
For $\mathrm{N}$, neither resorption efficiency nor proficiency was significantly related to soil total $\mathrm{N}$ or $\mathrm{C}$ or any of the $\mathrm{P}$ pools we considered. There was a marginally significant $(P=0.10)$ decline in the ratio of $\mathrm{N}: \mathrm{P}$ resorption with increasing soil $\mathrm{N}$, reflecting the strong relationship observed between $\mathrm{P}$ resorption and soil $\mathrm{N}$.

\section{Species-level $N$ and $P$ resorption}

We characterized $\mathrm{N}$ and $\mathrm{P}$ resorption in the six most common tree species in our stands. There were a few differences in resorption efficiencies by species (Fig. 4). Prunus pensylvanica, an early-successional species, had lower $\mathrm{N}$ and $\mathrm{P}$ resorption efficiency $(P<0.001)$ and proficiency $(P<0.001)$ than the other five species in the study (Fig. 4). In addition, $\mathrm{N}$ resorption proficiencies were higher in the two Acer species than in the other species (Fig. 4c).

We found single-element relationships between soil nutrients and resorption in some species, in spite of the smaller number of observations (none of the species was present in all of the stands). Phosphorus resorption efficiency was high where resin $\mathrm{P}$ was low in the Oe horizon in two species, $F$. grandifolia and $B$. alleghaniensis (Appendix C). Similarly, P resorption proficiency 

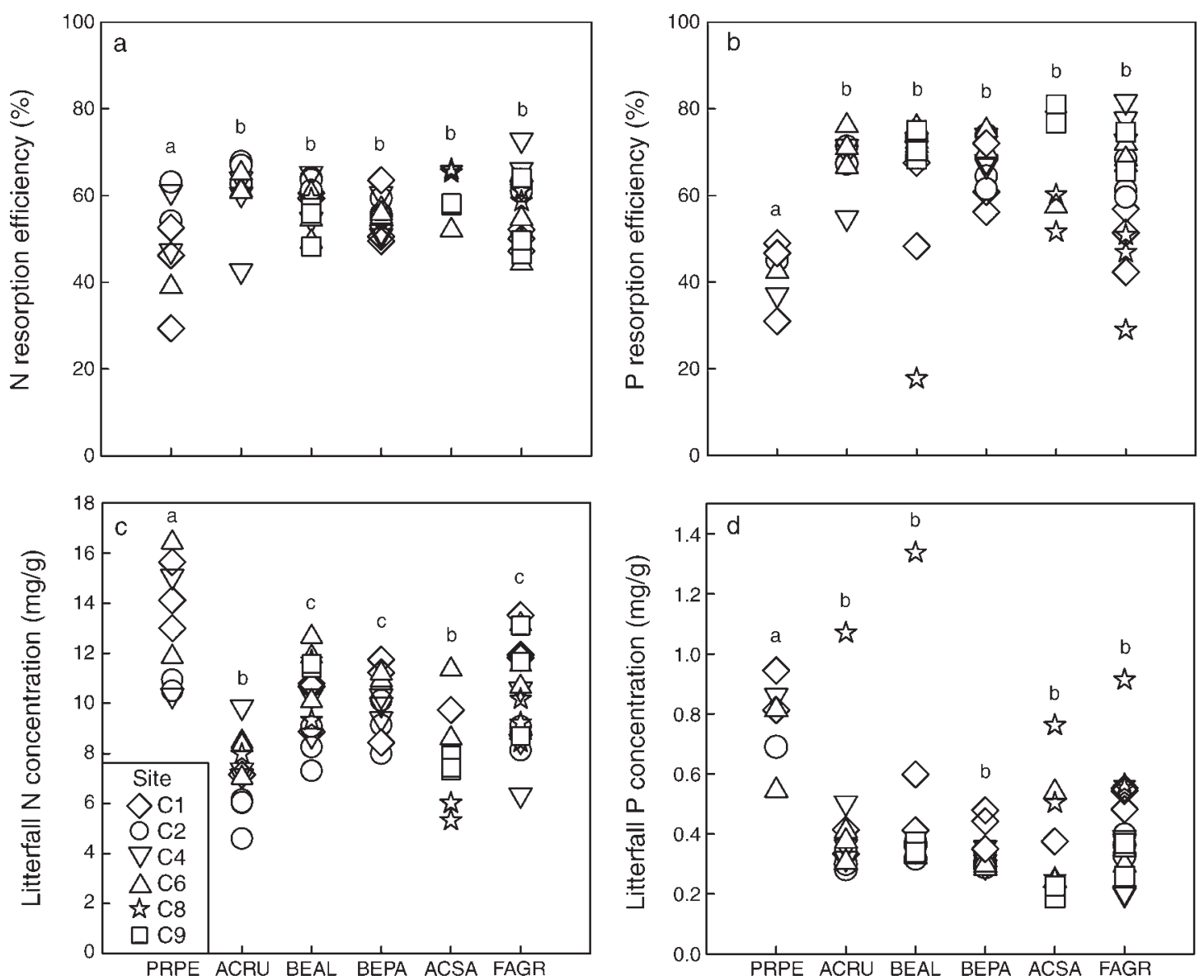

FIG. 4. Species-level N and P resorption efficiency and litter concentrations (resorption proficiency) by plot. Species that do not share a letter have significantly different means across all plots $(\alpha=0.05$ ). Pin cherry (Prunus pensylvanica) had lower efficiencies $(\mathrm{a}, \mathrm{b})$ and proficiencies $(\mathrm{c}, \mathrm{d})$ for both $\mathrm{N}(\mathrm{a}, \mathrm{c})$ and $\mathrm{P}(\mathrm{b}, \mathrm{d})$. Species codes are PRPE (Prunus pensylvanica), ACRU (Acer rubrum), BEPA (Betula papyrifera), FAGR (Fagus grandifolia), BEAL (Betula alleghaniensis), and ACSA (Acer saccharum).

was related to resin $\mathrm{P}$ in those two species plus the two Acer species (Appendix C). As with the community-level results, bicarbonate-extractable $\mathrm{P}$ was not correlated with $\mathrm{P}$ resorption efficiency (Fig. 5b) or proficiency (Appendix C) in any of the species we studied. We found higher $\mathrm{N}$ resorption efficiency in $P$. pensylvanica (Fig. $5 \mathrm{~d}$ ) and $\mathrm{N}$ resorption proficiency in $B$. papyrifera (Appendix $\mathrm{C}$ ) in plots with lower $\mathrm{N}$ mineralization potential in the Oa horizon. Similarly, we found higher $\mathrm{N}$ resorption efficiency in $B$. alleghaniensis in plots with smaller $\mathrm{N}$ pools (Fig. 5f).

For individual species, as for the tree community, $\mathrm{P}$ resorption tended to be higher where soil $\mathrm{N}$ pools were high. For P resorption proficiency, the relationship with soil $\mathrm{N}$ pools was significant for $A$. saccharum and $B$. papyrifera (Appendix C), and for $\mathrm{P}$ resorption efficiency, the relationship was significant for these species plus $F$. grandifolia (Fig. 5c). Thus we found both multipleelement relationships and single-element relationships in the species-level data.

\section{Discussion}

The primary goal of this research was to evaluate single-element vs. multiple-element explanations for variability in foliar nutrient resorption. A single-element model of $\mathrm{P}$ resorption would predict greater $\mathrm{P}$ resorption where soil $\mathrm{P}$ availability is low. We found this pattern when comparing both $\mathrm{P}$ resorption efficiency and proficiency to resin-available $\mathrm{P}$ concentrations in the Oe horizon (Fig. 2b, Table 2), but not when comparing $\mathrm{P}$ resorption to estimates of $\mathrm{P}$ availability in the $\mathrm{Oa}$ horizon or the mineral soil (Table 2). An alternate explanation for high $\mathrm{P}$ resorption where $\mathrm{P}$ availability is low is that $\mathrm{P}$ availability in the Oe horizon is controlled by $\mathrm{P}$ resorption, rather than the other way around. Variation in P resorption efficiency reflects variation in litter concentrations, as green foliar concentrations were quite consistent. Since the Oe horizon consists primarily of decomposing leaf material, low concentrations of $\mathrm{P}$ in leaf litter would be expected to result in low $\mathrm{P}$ availability. Thus it may be problematic to interpret 

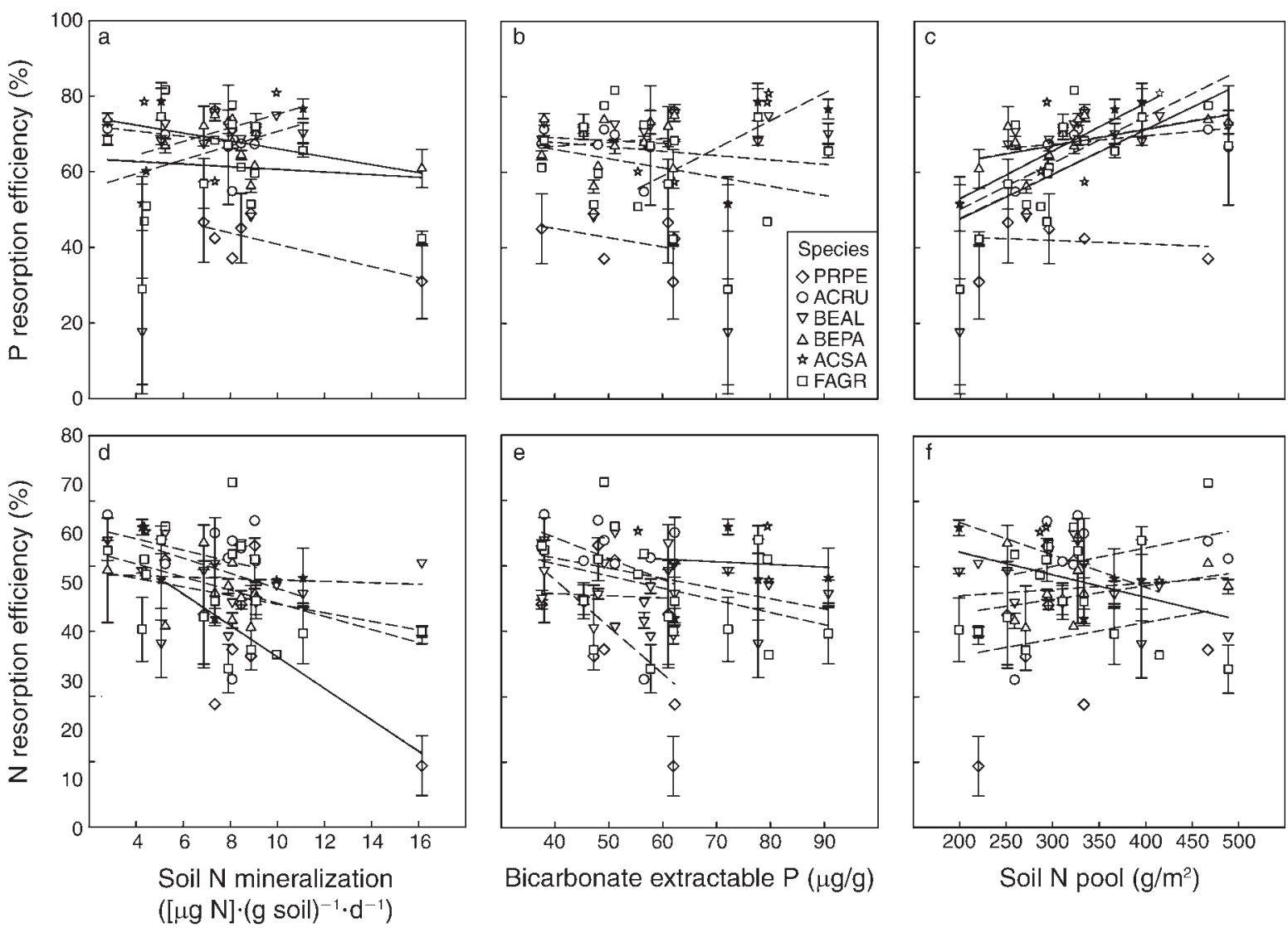

FIG. 5. Nutrient resorption efficiencies as a function of soil nutrients for six hardwood species. Simple linear regression lines are shown for each species. Solid lines denote significance at $\alpha=0.10$ based on a mixed model controlling for stand effects; dashed lines signify nonsignificant relationships. Bicarbonate-extractable $\mathrm{P}$ concentrations and $\mathrm{N}$ mineralization potentials shown were measured in the Oa horizon. Soil $\mathrm{N}$ contents were calculated from the Oa horizon to $30 \mathrm{~cm}$ depth in the mineral soil. Error bars show the standard error across two years.

resorption as a response to nutrient concentration in the Oe horizon.

When we compared $\mathrm{N}$ and $\mathrm{P}$ resorption to pools of $\mathrm{N}$ and $\mathrm{P}$ from the $\mathrm{Oa}$ to $30 \mathrm{~cm}$ depth in the mineral soil, we found no support for single-element controls over either $\mathrm{N}$ or $\mathrm{P}$ resorption. In fact, we found marginally significant increases in $\mathrm{P}$ resorption with increasing recyclable P pool size (Fig. 3c, Table 2). Increasing P resorption with increasing soil $\mathrm{P}$ is counterintuitive from a single-resource conservation standpoint, but has been observed in other studies (Boerner 1986, Sabate et al. 1995). Because soil $\mathrm{N}$ and $\mathrm{P}$ were correlated in our plots, an increase in $\mathrm{P}$ resorption with soil $\mathrm{N}$ resulted in a positive correlation between $\mathrm{P}$ resorption and soil $\mathrm{P}$. The influence of soil $\mathrm{N}$ status on $\mathrm{P}$ resorption could help to explain the lack of a common trend in studies comparing $\mathrm{P}$ resorption to soil $\mathrm{P}$ availability (Aerts 1996, Aerts and Chapin 2000).

Some recent fertilization experiments provide additional support for $\mathrm{N}$ control over $\mathrm{P}$ resorption. Longterm $\mathrm{N}$ additions to a boreal peatland increased $\mathrm{P}$ resorption efficiencies in two evergreen shrubs (Wang et al. 2014). Nitrogen fertilization in grasslands caused increased P resorption efficiency in some species but not others in Mongolia ( $\mathrm{Li}$ et al. 2012) and in northeastern China (Lu and Han 2010). In the latter study, soil P concentrations did not differ significantly from controls, suggesting that the observed changes in $\mathrm{P}$ resorption were not caused by decreased soil $\mathrm{P}$ availability following $\mathrm{N}$ addition. Our results provide evidence that soil $\mathrm{N}$ affects $\mathrm{P}$ resorption at the community level, and is the first to show such effects without experimental manipulation of soil $\mathrm{N}$ availability.

The natural variation in soil $\mathrm{N}$ and $\mathrm{P}$ availability within our study site was small relative to many previous studies of resorption response. Several studies focusing on the resorption response to relative $\mathrm{N}$ and $\mathrm{P}$ nutrient limitations have used chronosequences or edaphic gradients to capture a large range of soil conditions (e.g., Vitousek 1998, Richardson et al. 2008, Hayes et al. 2014). Despite the smaller range of conditions and spatial scale of this study, the ranges in foliar N:P ratios for species observed in our plots were nearly as wide as ranges reported across the entire region (Crowley et al. 2012), and the ranges in $P$ resorption efficiency we observed encompassed much of the variation seen 
globally (Aerts and Chapin 2000). Community-level N:P ratios were $>18$ in all but one stand (C8, Fig. 1), indicating some degree of $\mathrm{P}$ limitation according to commonly cited indices (Koerselman and Meuleman 1996, Güsewell 2004). Our plots all had N:P resorption efficiency ratios $<1$, another indication of $\mathrm{P}$ limitation (Reed et al. 2012). Plot C8-3 had the lowest foliar N:P ratio, and a corresponding $\mathrm{N}: \mathrm{P}$ resorption ratio nearly twice the mean of the other plots (Fig. 1), suggesting that a threshold of $\mathrm{N}$ limitation relative to $\mathrm{P}$ had been reached in this plot. While plot C8-3 had the smallest soil $\mathrm{N}$ pools and lowest $\mathrm{N}$ mineralization rate, it did not have the highest $\mathrm{N}$ resorption; rather, it had the lowest $\mathrm{P}$ resorption (Fig. 2). Since $\mathrm{P}$ resorption requires enzyme production, minimizing $\mathrm{P}$ resorption could be a mechanism of $\mathrm{N}$ conservation in this $\mathrm{N}$-limited plot.

McGroddy et al. (2004) proposed a two-pool model of resorption, consisting of a metabolically active pool that is relatively easily resorbed, and a more immobile, structurally bound pool that is not. Global patterns of $\mathrm{N}$ in litterfall are consistent with resorption of only the non-structural $\mathrm{N}$ pool (McGroddy et al. 2004). In contrast, for $\mathrm{P}$, the structural pool is subject to resorption. Across a soil $\mathrm{P}$ gradient in Borneo, trees in lower $\mathrm{P}$ sites resorbed a higher proportion of phospholipids and nucleic acids (Hidaka and Kitayama 2011). Resorption of these structural $\mathrm{P}$ fractions requires greater investments of both $\mathrm{N}$ and energy in hydrolytic enzymes than is required for the resorption of the metabolic P fractions (ATP, sugar phosphates, and other P esters; Fischer 2007). Thus high P resorption is favored when $\mathrm{N}$ is available and $\mathrm{P}$ is scarce. In contrast, high $\mathrm{P}$ availability does not seem to contribute to resorption of structural $\mathrm{N}$.

We observed high variation of $\mathrm{P}$ resorption relative to $\mathrm{N}$, despite the fact that variation in $\mathrm{N}$ mineralization was greater than variation in resin-available $\mathrm{P}$. This is consistent with the analysis of Aerts and Chapin (2000), which showed that differences in $\mathrm{P}$ resorption efficiency are important to leaf-level $\mathrm{P}$ use efficiency, while the most important strategy for leaf-level $\mathrm{N}$-use efficiency is low $\mathrm{N}$ concentration in fresh foliage. We conclude that resorption plays a more important role in plant conservation of $\mathrm{P}$ than $\mathrm{N}$ in this ecosystem, as in others.

Because litterfall $\mathrm{N}$ concentration was relatively consistent across our plots, the stoichiometry of ecosystem nutrient cycling via leaf litter depends on the factors controlling $\mathrm{P}$ resorption in this system. If $\mathrm{P}$ resorption is controlled by the availability of $\mathrm{N}$, as our data suggest, then high $\mathrm{N}$ availability in soil relative to $\mathrm{P}$ would result in greater $\mathrm{P}$ resorption and litter of higher $\mathrm{N}: \mathrm{P}$, creating a feedback loop that would accelerate the development of $\mathrm{P}$ limitation.

Substrate effects on microbial $\mathrm{C}$ mineralization may contribute to the relationship we found between low litterfall $\mathrm{P}$ concentration and high soil pools of $\mathrm{N}$ and $\mathrm{C}$ (Fig. 3). Decomposition is inhibited by both high $\mathrm{N}$ availability (Berg and McClaugherty 2014) and low P availability (Bradford et al. 2008, Strickland et al. 2010, Hartman and Richardson 2013), which promotes further accumulation of both $\mathrm{C}$ and $\mathrm{N}$ under $\mathrm{P}$ limitation. Indeed, nutrient additions to incubated soils from our plots showed that adding $\mathrm{P}$ increased microbial $\mathrm{C}$ mineralization of leaf litter, while adding $\mathrm{N}$ inhibited mineralization of soil organic matter (Fisk et al. 2015). Since $P$ resorption controls both the $P$ concentration and N:P ratios of leaf litter, it may also be indirectly controlling decomposition rates and therefore the accumulation of organic $\mathrm{N}$.

Overall, our data support the idea that resorption efficiencies in this system vary spatially to reflect differences in nutrient availability, with few differences among species. One exception was $P$. pensylvanica, which had significantly lower resorption efficiencies for both N and P (Fig. 4). Prunus pensylvanica is an early successional species present only in our younger stands ( $<40$ years), and is adapted to rapid growth under conditions of relatively high resource availability. A multiple-element ecosystem model applied to our study system suggests that trees in stands of this age should exert more effort towards $\mathrm{N}$ than $\mathrm{P}$ acquisition (Rastetter et al. 2013). Despite its overall lower $\mathrm{N}$ resorption efficiency, $P$. pensylvanica was the only species in which we detected a significant decrease in $\mathrm{N}$ resorption with increasing $\mathrm{N}$ mineralization rates (Fig. 5d). Addition of balanced, complete fertilizer to $P$. pensylvanica stands in the White Mountains reduced both $\mathrm{N}$ and $\mathrm{P}$ resorption and increased the length of time the species was able to persist among later successional species, possibly due to a release from the pressure of nutrient competition (Fahey et al. 1998). Phosphorus resorption in B. papyrifera, the other early successional species in this community, did not differ from the climax community species.

The biological mechanisms for maintaining $\mathrm{N}$ and $\mathrm{P}$ stoichiometry in plants include both acquisition and conservation. To date, research on ecosystem $\mathrm{P}$ cycling in response to $\mathrm{N}$ has focused primarily on soil $\mathrm{P}$ acquisition. Foliar nutrient resorption is the most important mechanism of $\mathrm{P}$ conservation, and our results show a strong effect of soil $\mathrm{N}$ on $\mathrm{P}$ resorption. A response of $\mathrm{P}$ resorption to changing ecosystem $\mathrm{N}$ status could provide an important mechanism for the coupled cycling of $\mathrm{N}$ and $\mathrm{P}$ and should be explored in other terrestrial systems.

\section{ACKNOWLEDGMENTS}

We thank Keith Killingbeck, Mariann Johnston, Rebecca Walling, and two anonymous reviewers for extremely helpful feedback on earlier versions of this manuscript. Quinn Thomas assisted with the collection of leaves and litter. Pilar Lyons and Bill O'Neill assisted with foliar nutrient analysis. Heather Engelman provided invaluable assistance with logistical management. The Bartlett Experimental Forest is operated by the USDA Forest Service Northern Research Station. This work is a product of MELNHE (www.esf.edu/melnhe/), and was supported by grants DEB 0949324 and 0235650 from the National Science Foundation. 


\section{Literature Cited}

Aerts, R. 1996. Nutrient resorption from senescing leaves of perennials: Are there general patterns? Journal of Ecology 84: 597-608.

Aerts, R., and F. S. Chapin, III. 2000. The mineral nutrition of wild plants revisited: a re-evaluation of processes and patterns. Advances in Ecological Research 30:1-67.

Aerts, R., and H. De Caluwe. 1994. Nitrogen use efficiency of Carex species in relation to nitrogen supply. Ecology 75 : 2362-2372.

Barton, K. 2014. MuMIn: multi-model inference. R package version 1.10.0. http://cran.r-project.org/package=MuMIn

Berg, B., and C. McClaugherty. 2014. Plant litter: decomposition, humus formation, carbon sequestration. Third edition. Springer, Berlin, Germany.

Bloom, A. J., F. S. Chapin, III, and H. A. Mooney. 1985. Resource limitation in plants: an economic analogy. Annual Review of Ecology and Systematics 16:363-392.

Boerner, R. E. J. 1984. Foliar nutrient dynamics and nutrient use efficiency of four deciduous tree species in relation to site fertility. Journal of Applied Ecology 21:1029-1040.

Boerner, R. E. J. 1986. Seasonal nutrient dynamics, nutrient resorption, and mycorrhizal infection intensity of two perennial forest herbs. American Journal of Botany 73: 1249-1257.

Bowman, W. D., T. A. Theodose, and M. C. Fisk. 1995. Physiological and production responses of plant growth forms to increases in limiting resources in alpine tundra: implications for differential community responses to environmental change. Oecologia 101:217-227.

Bradford, M. A., N. Fierer, and J. F. Reynolds. 2008. Soil carbon stocks in experimental mesocosms are dependent on the rate of labile carbon, nitrogen, and phosphorus inputs to soils. Functional Ecology 22:964-974.

Chapin, F. S., III, and L. Moilanen. 1991. Nutritional controls over nitrogen and phosphorus resorption from Alaskan birch leaves. Ecology 72:709-715.

Cleveland, C. C., B. Z. Houlton, W. K. Smith, A. R. Marklein, S. C. Reed, W. Parton, S. J. Del Grosso, and S. W. Running. 2013. Patterns of new versus recycled primary production in the terrestrial biosphere. Proceedings of the National Academy of Sciences USA 110:12733-12737.

Crowley, K. F., et al. 2012. Do nutrient limitation patterns shift from nitrogen toward phosphorus with increasing nitrogen deposition across the northeastern United States? Ecosystems 15:940-957.

Elser, J. J., M. E. S. Bracken, E. E. Cleland, D. S. Gruner, W. S. Harpole, H. Hillebrand, J. T. Ngai, E. W. Seabloom, J. B. Shurin, and J. E. Smith. 2007. Global analysis of nitrogen and phosphorus limitation of primary producers in freshwater, marine and terrestrial ecosystems. Ecology Letters 10: $1135-1142$.

Enoki, T., and H. Kawaguchi. 1999. Nitrogen resorption from needles of Pinus thunbergii Parl. growing along a topographic gradient of soil nutrient availability. Ecological Research 14: $1-8$.

Fahey, T. J., J. T. Battles, and G. F. Wilson. 1998. Responses of early successional northern hardwood forests to changes in nutrient availability. Ecological Monographs 68:183-212.

Fischer, A. M. 2007. Nutrient remobilization during leaf senescence. Pages 87-107 in S. Gan, editor. Senescence processes in plants. Blackwell, Ames, Iowa, USA.

Fisk, M. C., T. J. Ratliff, S. Goswami, and R. D. Yanai. 2013. Synergistic soil response to nitrogen plus phosphorus fertilization in hardwood forests. Biogeochemistry 118:195204.

Fisk, M. C., S. Santangelo, and K. Minick. 2015. Carbon mineralization is promoted by phosphorus and reduced by nitrogen addition in the organic horizon of northern hardwood forests. Soil Biology \& Biogeochemistry 81:212218.

Galloway, J. N., J. D. Aber, J. W. Erisman, S. P. Seitzinger, R. W. Howarth, E. B. Cowling, and B. J. Cosby. 2003. The nitrogen cascade. BioScience 53:341-356.

Güsewell, S. 2004. N:P ratios in terrestrial plants: variation and functional significance. New Phytologist 164:243-266.

Han, W., L. Tang, Y. Chen, and J. Fang. 2013. Relationship between the relative limitation and resorption efficiency of nitrogen vs phosphorus in woody plants. PLoS ONE 8: e83366.

Harpole, W. S., et al. 2011. Nutrient co-limitation of primary producer communities. Ecology Letters 14:852-862.

Hartman, W. H., and C. J. Richardson. 2013. Differential nutrient limitation of soil microbial biomass and metabolic quotients $\left(q \mathrm{CO}_{2}\right)$ : is there a biological stoichiometry of soil microbes? PLoS ONE 8:1-14.

Hayes, P., B. L. Turner, H. Lambers, and E. Laliberte. 2014. Foliar nutrient concentrations and resorption efficiency in plants of contrasting nutrient-acquisition strategies along a 2million-year dune chronosequence. Journal of Ecology 102: $396-410$.

Hidaka, H., and K. Kitayama. 2011. Allocation of foliar phosphorus fractions and leaf traits of tropical tree species in response to decreased soil phosphorus availability on Mount Kinabalu, Borneo. Journal of Ecology 99:849-857.

Killingbeck, K. T. 1986. The terminological jungle revisited: making a case for use of the term resorption. Oikos 46:263264.

Killingbeck, K. T. 1996. Nutrients in senesced leaves: keys to the search for potential resorption and resorption efficiency. Ecology 77:1716-1727.

Kobe, R. K., C. A. Lepczyk, and M. Iyer. 2005. Resorption efficiency decreases with increasing green leaf nutrients in a global data set. Ecology 86:2780-2792.

Koerselman, W., and A. F. M. Meuleman. 1996. The vegetation N:P ratio: a new tool to detect the nature of nutrient limitation. Journal of Applied Ecology 33:14411450.

Lal, C. B., C. Annapurna, A. S. Raghubanshi, and J. S. Singh. 2001. Effect of leaf habit and soil type on nutrient resorption and conservation in woody species of a dry tropical environment. Canadian Journal of Botany 79:1066-1075.

Li, L. J., D. H. Zeng, R. Mao, and Z. Y. Yu. 2012. Nitrogen and phosphorus resorption of Artemisia scoparia, Chenopodium acuminatum, Cannabis sativa, and Phragmites communis under nitrogen and phosphorus additions in a semiarid grassland, China. Plant Soil and Environment 58:446-451.

Lu, X. T., and X. G. Han. 2010. Nutrient resorption responses to water and nitrogen amendment in semi-arid grassland of Inner Mongolia, China. Plant and Soil 327:481-491.

Lucash, M. S., R. D. Yanai, J. D. Blum, and B. B. Park. 2012. Foliar nutrient concentrations related to soil sources across a range of sites in the Northeastern United States. Soil Science Society of America Journal 76:674-683.

McGroddy, M. E., T. Daufresne, and L. O. Hedin. 2004. Scaling of $\mathrm{C}: \mathrm{N}: \mathrm{P}$ stoichiometry in forests worldwide: implications of terrestrial Redfield-type ratios. Ecology 85: $2390-2401$.

Murphy, J., and J. P. Riley. 1962. A modified single solution method for determination of phosphates in natural waters. Analytica Chimica Acta 27:31-36.

Nakagawa, S., and H. Schielzeth. 2013. A general and simple method for obtaining $R^{2}$ from generalized linear mixedeffects models. Methods in Ecology and Evolution 4:133142.

Nambiar, E. K. S., and D. N. Fife. 1987. Growth and nutrient retranslocation in needles of radiata pine in relation to nitrogen supply. Annals of Botany 60:147-156.

Nezat, C. A., J. D. Blum, R. D. Yanai, and S. P. Hamburg. 2007. A sequential extraction to determine the distribution of 
apatite in granitoid soil mineral pools with application to weathering at the Hubbard Brook Experimental Forest, NH, USA. Applied Geochemistry 22:2406-2421.

Norby, R. J., T. M. Long, J. S. Hartz-Rubin, and E. G. O'Neill. 2000. Nitrogen resorption in senescing tree leaves in a warmer, $\mathrm{CO}_{2}$-enriched atmosphere. Plant and Soil 224:15-29.

Olsen, S. R., C. V. Cole, F. S. Watanabe, and L. A. Dean. 1954. Estimation of available phosphorus in soils by extraction with sodium bicarbonate. U.S. Department of Agriculture Circular No 939. USDA, Washington, D.C., USA.

Park, B. B., R. D. Yanai, M. A. Vadeboncoeur, and S. P. Hamburg. 2007. Estimating root biomass in rocky soils using pits, cores, and allometric equations. Soil Science Society of America Journal 71:206-213.

Pinheiro, J., D. Bates, S. DebRoy, D. Sarkar, and R Core Team. 2014. nlme: linear and nonlinear mixed effects models. $\mathrm{R}$ package version 3.1-117. http://CRAN.R-project.org/ package $=$ nlme

Rastetter, E. B., R. D. Yanai, R. Q. Thomas, M. A. Vadeboncoeur, T. J. Fahey, M. C. Fisk, B. L. Kwiatkowski, and S. P. Hamburg. 2013. Recovery from disturbance requires resynchronization of ecosystem nutrient cycles. Ecological Applications 23:621-642.

Reed, S. C., A. R. Townsend, E. A. Davidson, and C. C. Cleveland. 2012. Stoichiometric patterns in foliar nutrient resorption across multiple scales. New Phytologist 196:173180.

Richardson, S. J., R. B. Allen, and J. E. Doherty. 2008. Shifts in leaf N:P ratios during resorption reflect soil $\mathrm{P}$ in temperate rainforest. Functional Ecology 22:738-745.

Richter, D. D., H. L. Allen, L. Jianwei, D. Markewitz, and J. Raikes. 2006. Bioavailability of slowly cycling soil phosphorus: major restructuring of soil $\mathrm{P}$ fractions over four decades in an aggrading forest. Oecologia 150:259-271.

Sabate, S., A. Sala, and C. A. Gracia. 1995. Nutrient content in Quercus ilex canopies: seasonal and special variation within a catchment. Plant and Soil 168-169:297-304.

Schlesinger, W. H., E. H. DeLucia, and W. D. Billings. 1989. Nutrient-use efficiency of woody plants on contrasting soils in the western Great Basin, Nevada. Ecology 70:105-113.
Stachurski, A., and J. R. Zimka. 1975. Methods of studying forest ecosystems: leaf area, leaf production, and withdrawal of nutrients from leaves of trees. Ekologia Polska 23:637648.

Strickland, M. S., M. A. Callaham, C. A. Davies, C. L. Lauber, K. Ramirez, D. D. Richter, N. Fierer, and M. A. Bradford. 2010. Rates of in situ carbon mineralization in relation to land-use, microbial community, and edaphic characteristics. Soil Biology and Biochemistry 42:260-269.

Vadeboncoeur, M. A. 2010. Meta-analysis of fertilization experiments indicates multiple limiting nutrients in northeastern deciduous forests. Canadian Journal of Forest Research 40:1766-1780.

Vadeboncoeur, M. A., S. P. Hamburg, J. D. Blum, M. J. Pennino, R. D. Yanai, and C. E. Johnson. 2012. The quantitative soil pit method for measuring belowground carbon and nitrogen stocks. Soil Society of America Journal 76:2241-2255.

Vadeboncoeur, M. A., S. P. Hamburg, R. D. Yanai, and J. D. Blum. 2014. Rates of sustainable forest harvest depend on rotation length and weathering of soil minerals. Forest Ecology and Management 318:194-205.

Vergutz, L., S. Manzoni, A. Porporato, R. F. Novais, and R. B. Jackson. 2012. Global resorption efficiencies and concentrations of carbon and nutrients in leaves of terrestrial plants. Ecological Monographs 82:205-220.

Vitousek, P. M. 1998. Foliar and litter nutrients, nutrient resorption, and decomposition in Hawaiian Metrosideros polymorpha. Ecosystems 1:401-407.

Vitousek, P. M., S. Porder, B. Z. Houlton, and O. A. Chadwick. 2010. Terrestrial phosphorus limitation: mechanisms, implications, and nitrogen-phosphorus interactions. Ecological Applications 20:5-15.

Wang, M., M. T. Murphy, and T. R. Moore. 2014. Nutrient resorption of two evergreen shrubs in response to long-term fertilization in a bog. Oecologia 174:1432-1939.

Yanai, R. D. 1992. Phosphorus budget of a 70-year-old northern hardwood forest. Biogeochemistry 17:1-22.

Yuan, Z. Y., and H. Y. H. Chen. 2015. Negative effects of fertilization on plant nutrient resorption. Ecology 96:373380 .

\section{Supplemental Material}

\section{Ecological Archives}

Appendices A-C are available online: http://dx.doi.org/10.1890/15-0188.1.sm 